\title{
EFFECTIVENESS OF SMOCKED THROW PILLOW PRODUCTION AS WORK DETERMINANT AMONG THE TRAINER: INPUT TO COMMUNITY IMPROVEMENT PLAN FOR RESEARCH AND EXTENSION OF LSPU
}

\author{
Dr. Henly F. Martirez, Dr. Evelyn A. Sunico, Dr. Lolita G. Perez, \\ Mrs. Marites D. Carlos
}

Article DOI: https://doi.org/10.36713/epra6881

DOI No: 10.36713/epra6881

\begin{abstract}
This study shows that there is effectiveness of smocked throw pillow production as work determinant among the trainer: input to community improvement plan for research and extension of $L S P U$, it sought to answer the following evaluation questionnaire, (1) Work Determinant among the Trainer in terms as a Trainee, Perception on trainors manner in handling trainees and Coordination and Networking, (2) Community Improvement Plan in terms of Beneficiaries are participating in all stages of the production, Local skill, knowledge and practices are mobilized in the production, Programs emphasize gender sensitivity, Systematic process of production, Program planning Implementation monitoring and assessment of effectiveness, Organizational structure and management

And Program emphasize gender sensitivity, (3) Is there significant difference between the Productions as Work among the Trainer to Community Improvement Plan?

The descriptive method was used in this study shows that there is effectiveness of smocked throw pillow production as work determinant among the trainer: input to community improvement plan for research and extension of LSPU. The questionnaire was used in the collection of data. The statistical treatment used was mean and standard deviation.

Based on the gathered data of this study, the findings of this study were the following: (1) Work Determinant among the Trainer in terms as a Trainee. The average mean of 4.26 and standard deviation of 0.64 with verbal interpretation Extremely Acceptable. Work Determinant among the Trainer in terms as Perception on trainors manner in handling trainees. The average mean of 4.24 and standard deviation of 0.65 with verbal interpretation Extremely Acceptable. Work Determinant among the Trainer in terms of Coordination and Networking. The average mean of 4.24 and standard deviation of 0.65 with verbal interpretation with Extremely Acceptable. (2) Community Improvement Plan in terms of Beneficiaries is participating in all stages of the production. The average mean of 4.63 and standard deviation of 0.60 with verbal interpretation Extremely Acceptable. Community Improvement Plan in terms of skill, knowledge and practices are mobilized in the production. The average mean of 4.24 and standard deviation of 0.66 with verbal interpretation Extremely Acceptable. Community Improvement Plan in terms of Programs emphasizes gender sensitivity. The average mean of 4.24 and standard deviation of 0.68 with verbal interpretation Extremely Acceptable. Community Improvement Plan in terms of Systematic process of production. The average mean of 4.25 and standard deviation of 0.66 with verbal interpretation Extremely Acceptable. Community Improvement Plan in terms of Program planning Implementation monitoring and assessment of effectiveness. The average mean of 4.25 and standard deviation of 0.66 with verbal interpretation Extremely Acceptable. Community Improvement Plan in terms of Organizational structure and management. The average mean of 4.24 and standard deviation of 0.63 with verbal interpretation Extremely Acceptable. Community Improvement Plan in terms of

Program emphasizes gender sensitivity. The average mean of 4.24 and standard deviation of 0.65 with verbal interpretation Extremely Acceptable. (3) There is significant effect between the Work determinant among the Trainer and Community Improvement Plan since the computed t-values is 3.27 and it is higher than critical t-value of 1.68 regardless of it sign.

Based on the findings of the study, the following conclusions were made. The respondents' Work Determinant among the Trainer in terms as a Trainee, Perception on trainors manner in handling trainees and Coordination and Networking were Extremely Acceptable. Community Improvement Plan in terms of Beneficiaries are participating in all stages of the production, Local skill, knowledge and practices are mobilized in the production, Programs emphasize gender sensitivity, Systematic process of production, Program planning Implementation monitoring and assessment of effectiveness, Organizational structure and management and Program emphasize gender sensitivity were Extremely Acceptable. There significant effect between the work determinant among the trainer and community improvement plan. The following were recommended: (1) Recommend producing more Smocked Throw Pillow. (2) To instruct the community to make smoked throw pillow for their livelihood. (3) To show creative ways make Smoked Throw Pillow.
\end{abstract}




\section{Importance of the Problem}

1. What is the mean level of Work Determinant among the Trainer?

1.1 as a Trainee

1.2 Perception on trainors manner in handling trainees

1.3 Coordination and Networking

2. What is the mean level of Community Improvement Plan?

2.1 Beneficiaries are participating in all stages of the production

2.2 Local skill, knowledge and practices are mobilized in the production

2.3 Programs emphasize gender sensitivity

2.4 Systematic process of production

2.5 Program planning Implementation monitoring and assessment of effectiveness

2.6 Organizational structure and management

2.7 Program emphasize gender sensitivity

3. Is there significant difference between the Productions as Work among the Trainer to Community Improvement Plan?

\section{LITERATURE}

Roldan( 2007) suggested that marketing strategy is a process that can allow the organization to concentrate its limited resources on the greatest opportunities to increase sales and achieve a sustainable competitive. Marketing strategy includes all basic and long term activities in the field of marketing that deal with the analysis of the strategic initial situation of a company and the formulation, evaluation and selection of market-oriented strategies and therefore contributes to the goals of the company and its marketing objectives.

Likewise, Shock (2007) said that marketing strategy design to be the vehicle use to achieve your marketing objectives, marketing tactics, are the specific tools use to support strategies.

Subsequently, Fajardo (2008) stated that marketing strategy is a written plan which combines product, promotion, development, distribution and pricing approach identifies the firm marketing goals and explains how the will be achieved within the stated time frame.

On the other hand, Lee et al. (2007) said that marketing strategy has used by many business entity or company to continuously support the flow of the products to the market and to capture a big dominated market. It is also been used to kill the competition around your target market.

Moreover, Pride (2008) mentioned that marketing strategy involves three activities selecting one or more target markets, setting marketing objectives and developing and maintaining a marketing strategy that will produce mutually satisfying changes with target markets.

Literatures written above are related to the present study in the sense that it explains how the business can achieved their goals through the use of marketing strategy.

Product

Alcantara (2009) stated that the production variable relate directly to satisfying needs and wants of the target market. One must create products or Services with characteristics that fulfill those needs and want of its customer.

Subsequently, De Pena ( 2007) noted that product is a bundled of attributes and benefits designed to buyers to satisfy their needs, wants and demands, there product may both goods and services. Products that pass the prototype development must be exposed to the ultimate customers in some reasonable realistic market environment. This is the learning and the turning period as the total offering would be tested in the market to ensure that all dimensions are working together and in a way that marketer should assumed they would. (Mayacay 2008)

Similarly, Palacio (2007) directed that product is the unique combination of goods and services that satisfies a want and need of customers.

Moreover, Abella (2009) stated that the product variable directly to satisfying the needs and wants of customers.

The above mentioned studies are related to the present study because products is anything that can be offered to a market for attention, acquisition, use or consumption that might satisfy a want or need.

Young and Pagoso (2010) stated that produced is anything that can be offered in the market for attention acquisition, use, or consumption to satisfy a needs and demands or expectation. It may include physical objects, persons, ideas, and services as well.

On the other hand, Lizardo ( 2011) emphasizes that product must be considered as a "“ value for-money" product, which simply means that the product in exchange for the registration or joining fee must have equivalent, if not higher, peso value. In addition, product must be unique and innovative. If the company offers product that are just used to have a semblance of legality and induce potential distributors are just used to have a semblance of legality and induce potential distributors to join.

According to Kotler ( 2007) proposed that the product is anything that can be offered to satisfied a wants and need to supposed that van executive feels and need to reduce the stress of the job in a highly competitive industry. The concept of product is not limited to physical object.

Likewise, Lawley (2012) stressed out the first factor for success is building a well thought out, prioritized product roadmap. A highly product roadmap often means the difference between success and failure when delivering and marketing products. 
Product must deliver a good customer experience when it becomes when it becomes widely available.

According to Pollack (2007) if a product fulfills the consumer's expectations, the consumer will be pleased and consider that the product is of acceptable or even with high quality. If his or her expectations are not fulfilled, the consumer will consider that the product is low quality. This means that the quality of a product may be defined as its ability to fulfill the consumers' needs and expectations.

Literatures written above are related to the present study because product help the consumer makes decisions to satisfy their needs or wants.

Product Quality

The product quality is an important manufacturing requirement because consumers are susceptible to any form of contamination that may occur during the manufacturing processing standards.. Evans (2007).

On the other hand, Lunberge and Walker (2008) stated that the product quality is what business patrons consider the most important factors when starting a business.

According to Hitt ( 2007), product quality exist when the firm's good or services meet or exceed customer's expectations, well-established one's relating to the production of goods and services with zero defects and seeing it as a never ending cycle of continuous improvement.

Moreover, Schewe (2008) defined that product quality is a meeting of customer's needs and expectation. All quality improvements must begin with an understanding of customers' needs and perception. Quality in the broadest sense is anything that can be improved.

The above mentioned literatures analyzed that product quality is an important food manufacturing requirements and it exist when the firm's good services meet or exceed customer's expectations in the product offered.

Promotion

Promotion is the way of communication tools are very important to marketing such the business communications with its market Good communication tools are very important to marketing success and should be built into the marketing plan. It is through promotion that the entrepreneurs inform the potential customers. It is more interesting field of marketing, promotion often with advertising.

Stefanelli (2007) stated that promotion is the overall message you relay to your target market, including advertising, sales promotion, personal selling and public relation efforts.

Similarly, Thesis (2008) said that the promotion involves all communication with the customers. It introduces the customer to, or increase customer awareness of the valuable product.

Furthermore, Weaver and Lawton (2007) mentioned that promotion attempts to increase demand by conveying a positive image of the product to potential customers through appeals to perceived demands, needs, tastes, values and attitudes of the market or a particular target market segment.

The above literatures are related in the present study because promotion is the business of communicating with customers' atmosphere in the product.

Price

According to Makens (2007) price refers to the amount of money charged for a goods or services. More broadly, it is the sum of the values consumers exchange for the benefits of having or using the product or service.

Correspondingly, Halloran (2008) stated that price is considered the hidden objection that it comes to selling. Many times the buyers are not provided not to buy because of the price of the products or services.

Evans (2010) said that price is the marketing tool that sells value to customers will want to buy, but high enough for the entrepreneur to make a reasonable profit.

Moreover, Azarcon et al. (2007) pointed out that price is prime consideration before a product is effectively said. Price refers to the actual amount of money tendered by customers before acquiring a products or services.

Portillo et al. (2007) stated that price is the amount of money charged for a product or sum of values customers exchange for the benefits of the products or services.

Literatures written above are related to the present study in the sense that price is the marketing tool that sells value to customer. It refers to the amount of money charged for a goods or services.

Costumer Evaluation

According to Payne (2008) the ultimate test of a successful planned menu is to determine the degree of satisfaction on the part of the customer. Although highly subjective satisfaction can be measure and evaluated over time using a member of technique including survey comment checklist frequency rating and sale data. Satisfaction

As stared by Joby (2010), organizations are increasingly interested in retaining the existing customers while targeting non-customers; measuring customer's satisfaction provides an indication of how successful the organization is at providing products or services to the market place. Furthermore, Quelch et al. (2010) said that customer satisfaction identifies the gaps between customer's expectation and their perceptions of what a company's delivering. Likewise, Evans (2008) stated that the customer satisfaction maybe influenced by many factors throughout the customer overall purchase, ownership and service experience. Correspondingly, Vessey (2008) pointed out that customer satisfaction is a person feeling of pleasure or disappointment resulting for comparing products or serviced 
perceived performance or outcome in relation to his/her expectation.

The above literatures are related to the present study in the sense that it stated that customer's satisfaction is an indication of how successful the organization is at providing goods or services to the market place.

According to Good Housekeeping: The Illustrated Book of Needlecrafts, "Any type of fabric can be smocked if it is supple enough to be gathered." Fabric can be gathered into pleats in a variety of ways. Early smocking, or gauging, was done by hand. Some embroiderers also made their own guides using cardboard and an embroidery marking pencil.[2] By 1880, iron-on transfer dots were available and advertised in magazines such as Weldon's. The iron on transfers places evenly spaced dots onto the wrong side of the fabric, which were then pleated using a regular running stitch. Since the early 1950 s, pleating machines have been available to home smockers. Using gears and specialty pleater needles, the fabric is forced through the gears and onto the threaded needles. Pleating machines are typically offered in 16-row, 24-row and 32-row widths. Manufacturers include Read and Amanda Jane. Smocking refers to work done before a garment is assembled. It usually involves reducing the dimensions of a piece of fabric to one-third of its original width, although changes are sometimes lesser with thick fabrics. Individual smocking stitches also vary considerably in tightness, so embroiderers usually work a sampler for practice and reference when they begin to learn smocking. Traditional hand smocking begins with marking smocking dots in a grid pattern on the wrong side of the fabric and gathering it with temporary running stitches. These stitches are anchored on each end in a manner that facilitates later removal and are analogous to basting stitches. Then a row of cable stitching stabilizes the top and bottom of the working area.

Smocking is an embroidery technique used to gather fabric so that it can stretch. Before elastic, smocking was commonly used in cuffs, bodices, and necklines in garments where buttons were undesirable. Smocking developed in England and has been practised since the Middle Ages and is unusual among embroidery methods in that it was often worn by laborers. Other major embroidery styles are purely decorative and represented status symbols. Smocking was practical for garments to be both form fitting and flexible, hence its name derives from smock - a farmer's work shirt. Smocking was used most extensively in the eighteenth and nineteenth centuries. Smocking requires lightweight fabric with a stable weave that gathers well. Cotton and silk are typical fiber choices, often in lawn or voile. Smocking is worked on a crewel embroidery needle in cotton or silk thread and normally requires three times the width of initial material as the finished item will have. Standard hand smocking stitches are:
A. Cable stitch: a tight stitch of double rows that joins alternating columns of gathers. B. Stem stitch: a tight stitch with minimum flexibility that joins two columns of gathers at a time in single overlapping rows with a downward slope. C. Outline stitch: similar to the stem stitch but with an upward slope. D. Cable flowerette: a set of gathers worked in three rows of stitches across four columns of gathers. Often organized in diagonally arranged sets of flowerettes for loose smocking. E. Wave stitch: a medium density pattern that alternately employs tight horizontal stitches and loose diagonal stitches. F. Honeycomb stitch: a medium density variant on the cable stitch that double stitches each set of gathers and provides more spacing between them, with an intervening diagonal stitch concealed on the reverse side of the fabric. G. Surface honeycomb stitch: a tight variant on the honeycomb stitch and the wave stitch with the diagonal stitch visible, but spanning only one gather instead of a gather and a space. $\mathrm{H}$. Trellis stitch: a medium density pattern that uses stem stitches and outine stitches to form diamond-shaped patterns. I. Vandyke stitch: a tight variant on the surface honeycomb stitch that wraps diagonal stitches in the opposite direction. J. Bullion stitch: a complex knotted stitch that joins several gathers in a single stitch. Organized similarly to cable flowerettes. Smocker's knot: (not depicted) a simple knotted stitch used to finish work with a thread or for decorative purposes.

Schultz Approach (1975) argues that entrepreneurship is closely connected to situations of disequilibria and that entrepreneurship is the ability to deal with these situations. In disequilibrium, agents are acting sub-optimally and can reallocate their resources to achieve a higher level of satisfaction. It also argues that entrepreneurship exists in all aspect of life. Thus, housewives and students are entrepreneurs when allocating their time for housework or student activities. Furthermore, since entrepreneurship is an ability that can be augmented by investment, Schultz argues that a market for entrepreneurship exists and that it is possible to analyze entrepreneurship within the conventional supply and demand framework (Hebert and Link, 1988).

Disconfirmation Model is based on the comparison of customer's expectations and their perceived performance ratings. Specifically, individual's expectations are confirmed when a product performs as expected. It is negatively confirmed when a product performs more poorly than expected. The disconfirmation is positive when a product performs over the expectations (Churchill \& Suprenant 1982) there are four constructs to describe the traditional disconfirmation paradigm mentioned as expectations, performance, disconfirmation and satisfaction. 


\section{INTRODUCTION}

Comfortable cotton pillow that have been using for a long period of time, has a variety of materials ranging from latex to foam that offer distinctive advantages. Latex pillows are highly beneficial in maintaining a constant temperature throughout the night that keeps comfortable and contributes to a sound sleep.

Pillows offer a range of health benefits to support spine and neck depending on the position during sleeping and where they are placed. Pillows used to offer temperature therapy and of a therapeutic pillow is magnetic pillows. Magnetic fields are known to offer various health benefits such as improving the overall quality of sleeping, alleviating blockage and irritation of sinuses and providing muscle relief by reducing strain.

Special types of pillows are available for health purposes and can be purchased for various uses such to support and aid a pregnant mother. An airplane neck pillow particularly useful as they wrap around the neck and allow to have a comfortable sleep irrespective of the motion of the vehicle. Travel pillows can also be used if work long or late shifts for a quick power nap at work.

Pillows serve a tangible purpose to purchased for its aesthetic value. Primarily to add a sense of décor rather than to be used. Most pillows that are purchased for decorative purposes have innovative designs and are often custom made. The aforementioned facts gave a better insight for the researcher to design another pillows on the shape and consistency otherwise ironically to negatively affect your health.

\section{METHODOLOGY}

The descriptive method of research was used in this study to determine the customer satisfaction on the production of Smoked Throw Pillow. Calderon and Sevilla (2003) states that the basic purpose of experimental research is to discover the influence of one or two factors upon a condition, group or situation, purpose of which to discover "what will be". It describes and analyzes variables in carefully controlled condition as a basis for inferring or concluding.

Population and Sampling Technique

In conducting a descriptive research to prepare Smoked Throw Pillow, the researchers choose selected respondents in this study.

\section{Data Gathering Procedures}

First the researchers choose what research study will do, then selecting the title of the research study. Then the researcher gathered data from books, internet, and other reading materials that have information about the research study in making the introduction and background of the study. Further citing the problem of the study and the scope and limitation is also included. It also includes the gathering and preparing the related literatures and studies. Preparing the Research Methodology will be the next procedure to work out, that includes research design, population sampling and technique, data gathering procedures, construction procedures, trials and revision, cost of production, cost of production, research instrument and the statistical treatment.

After the study will be formulated, a letter of request was submitted to the dean's office of Laguna State Polytechnic University to seek permission to conduct the study. A questionnaires checklist is the design to be used by respondents in evaluating the finished products to gather information needed for the pursuance of the study. Immediately after the permission/approval from the Dean the researchers distribute the questionnaires checklists to the respondents. The questionnaires checklist was retrieved and tallied for the interpretation and analysis of gathered data. After the data was collected, the questionnaires checklists were prepared for the statistical treatment using the formula.

Research Instrument

A questionnaires checklist was used to determine the marketing strategy in terms of product, promotion, price It is also used to determine customer satisfaction on the production of Smoked Throw Pillow in terms of product quality .Respondents were composed of selected professors

\section{Statistical Treatment}

The statistical treatment was used to analyze and interpret the data given by the respondents. After administering the questionnaires checklists to the respondents, all the data were gathered, analyzed and interpreted.

In order to determine the mean level of marketing strategy in terms of product, promotion and price as perceived by the respondents the researcher used the tabulated mean and standard deviation in analyzing the result.

In order to determine the mean level of customer satisfaction on the production of Smoked Throw Pillow as perceived by the respondents the researcher also used the tabulated mean and standard deviation in analyzing the result.

The regression was used to determine the significant effects between the marketing strategy and the customer evaluation on the production of Smoked Throw Pillow.

\section{RESULT AND DISCUSSION}

This data gathered, organized, and statistically treated. The data are analyzed. The data are analyzed and interpreted according to the research questions. 
Table 1. The Mean Level of Community Improvement Plan as a Trainee

\begin{tabular}{|c|c|c|c|}
\hline As a TRAINEES I, & MEAN & SD & INTERPRETATION \\
\hline $\begin{array}{l}\text { 1.Learned the techniques and methods for } \\
\text { smocked throe pillow production on how to } \\
\text { understand my responsibilities and duties so } \\
\text { that I can work effectively. }\end{array}$ & 4.25 & 0.54 & Extremely Acceptable \\
\hline $\begin{array}{l}\text { 2.Was highly motivated to learn strategies } \\
\text { that would heighten my level of persistence, } \\
\text { perseverance and tenacity to achieve goals in } \\
\text { baking. }\end{array}$ & 4.3 & 0.60 & Extremely Acceptable \\
\hline $\begin{array}{l}\text { 3.Knew very well the etiquettes and business } \\
\text { practices entrepreneur. }\end{array}$ & 4.33 & 0.62 & Extremely Acceptable \\
\hline $\begin{array}{l}\text { 4.Negotiated well with Trainor's and Head of } \\
\text { the extension Services. }\end{array}$ & 4.2 & 0.69 & Extremely Acceptable \\
\hline $\begin{array}{l}\text { 5.Adopted well and deal with different } \\
\text { situations arises. }\end{array}$ & 4.3 & 0.61 & Extremely Acceptable \\
\hline 6.Acquired the necessary training skills. & 4.08 & 0.55 & Very Acceptable \\
\hline $\begin{array}{l}\text { 7.Possessed good communication skills while } \\
\text { attending to training, demonstrated a high } \\
\text { degree of expertise and mastery of baking } \\
\text { skills and knowledge. }\end{array}$ & 4.43 & 0.72 & Extremely Acceptable \\
\hline $\begin{array}{l}\text { 8.Developed awareness between other } \\
\text { group's performances on baking. }\end{array}$ & 4.1 & 0.64 & Very Acceptable \\
\hline $\begin{array}{l}\text { 9. Learned to evaluate and constructively } \\
\text { tackled the challenges on bread and pastry } \\
\text { skill training could bring to the workplace. }\end{array}$ & 4.3 & 0.80 & Extremely Acceptable \\
\hline $\begin{array}{l}\text { 10.Was prepared to appreciate output of } \\
\text { other". }\end{array}$ & 4.2 & 0.79 & Extremely Acceptable \\
\hline Average Mean & 4.26 & 0.64 & Extremely Acceptable \\
\hline Rating & Description & \multicolumn{2}{|c|}{ Interpretation } \\
\hline $4.20-5.00$ & Strongly Agree & \multicolumn{2}{|c|}{ Extremely Acceptable } \\
\hline $3.40-4.19$ & Agree & \multicolumn{2}{|c|}{ Very Acceptable } \\
\hline $2.60-3.39$ & Moderately Agree & \multicolumn{2}{|c|}{ Moderately Acceptable } \\
\hline $1.80-2.59$ & Disagree & \multicolumn{2}{|c|}{ Slightly Acceptable } \\
\hline $1.00-1.79$ & Strongly Disagree & \multicolumn{2}{|c|}{ Not Acceptable } \\
\hline
\end{tabular}

The Mean Level of Community Improvement Plan as a Trainee. Learned the techniques and methods for smocked throe pillow production on how to understand my responsibilities and duties so that I can work effectively with the mean of 4.25 and standard deviation of 0.54 with the verbal interpretation of Extremely Acceptable. Was highly motivated to learn strategies that would heighten my level of persistence, perseverance and tenacity to achieve goals in baking with the mean of 4.3 and standard deviation of 0.60 with the verbal interpretation of Extremely Acceptable. Knew very well the etiquettes and business practices entrepreneur with the mean of 4.33 and standard deviation of 0.62 with the verbal interpretation of Extremely Acceptable. Negotiated well with Trainor's and Head of the extension Services with the mean of 4.2 and standard deviation of 0.69 with the verbal interpretation of Extremely Acceptable. Adopted well and deal with different situations arises with the mean of 4.3 and standard deviation of 0.61 with the verbal interpretation of Extremely Acceptable. Acquired the necessary training skills arise with the mean of 4.08 and standard deviation of 0.55 with the verbal interpretation of Very Acceptable. Possessed good communication skills while attending to training, demonstrated a high degree of expertise and mastery of baking skills and knowledge with the mean of 4.43 and standard deviation of 0.72 with the verbal interpretation of Extremely Acceptable. Developed awareness between other group's performances on baking with the mean of 4.1 and standard deviation of 0.64 with the verbal interpretation of Very Acceptable. Learned to evaluate and constructively tackled the challenges on bread and pastry skill training could bring to the workplace with the mean of 4.3 and standard deviation of 0.80 with the verbal interpretation of Extremely Acceptable. Was prepared to appreciate output of other with the mean of 4.2 and standard deviation of 0.79 with the verbal interpretation of Extremely Acceptable. Community Improvement 
EPRA International Journal of Multidisciplinary Research (IJMR) - Peer Reviewed Journal Volume: 7 | Issue: 4 | April 2021|| Journal DOI: 10.36713/epra2013 || SJIF Impact Factor 2021: 8.047 || ISI Value: 1.188

Plan as a Trainee average mean of 4.26 and standard deviation 0.64 with the verbal interpretation of

Extremely Acceptable.

Table 2. The Mean Level of Community Improvement Plan as a Perception on Trainor's manners in handling Trainees on smocked throw pillows in terms of Personal Expertise

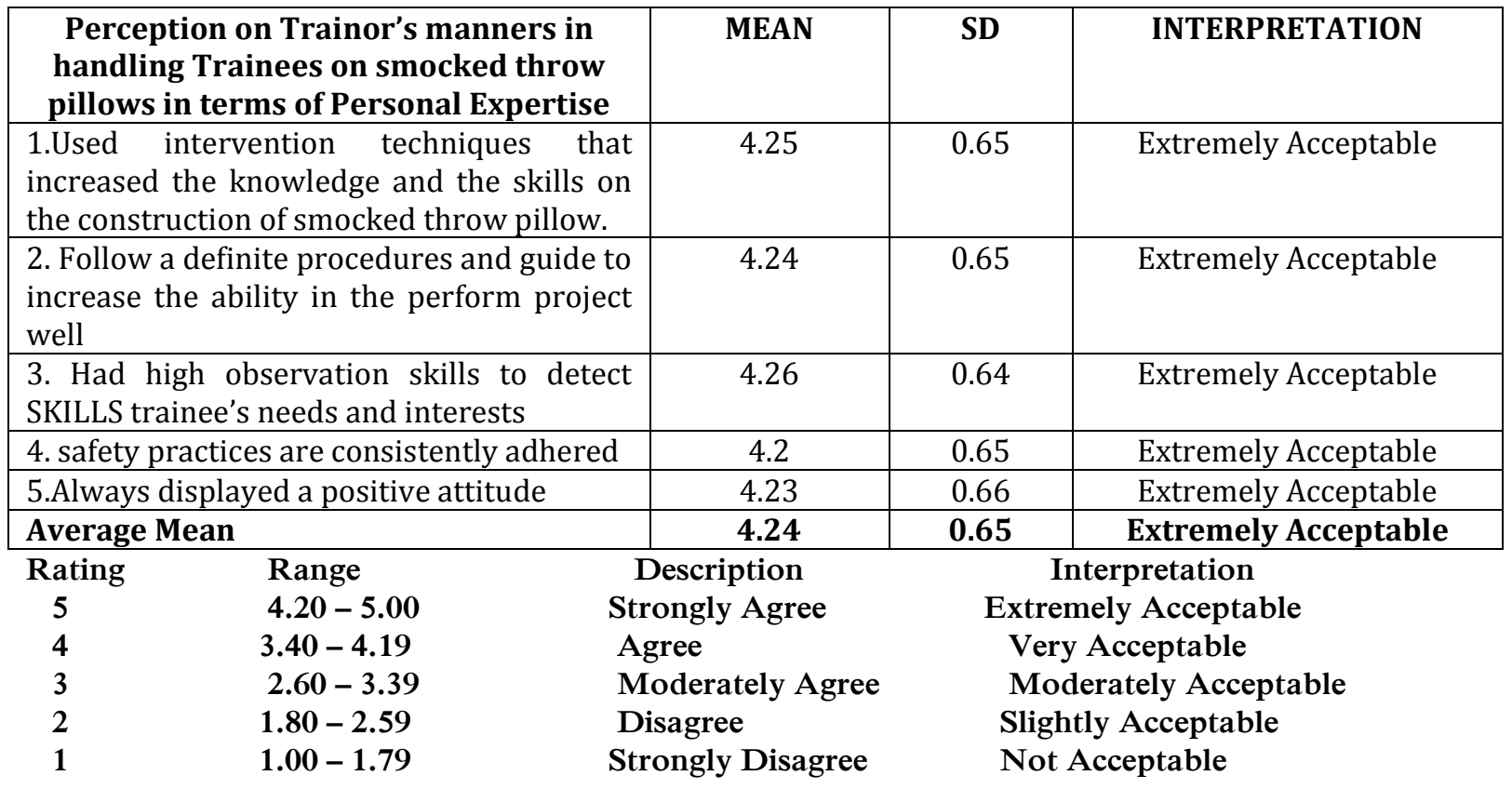

The Mean Level of Community Improvement Plan as a Perception on Trainor's manners in handling Trainees on smocked throw pillows in terms of Personal Expertise. Used intervention techniques that increased the knowledge and the skills on the construction of smocked throw pillow with the mean of 4.25 and standard deviation of 0.65 with the verbal interpretation of Extremely Acceptable. Follow a definite procedures and guide to increase the ability in the perform project well with the mean of 4.24 and standard deviation of 0.65 with the verbal interpretation of Extremely Acceptable. Had high observation skills to detect SKILLS trainee's needs and interests with the mean

Table 3. The Mean Level of Community Improvement Plan as Work Determinants in Skills Training on Smocked Throw Pillow in terms of Coordination and Net Working.

\begin{tabular}{|c|c|c|c|}
\hline Coordination and net working & MEAN & SD & INTERPRETATION \\
\hline $\begin{array}{l}\text { 1. Active coordination with major } \\
\text { stakeholders }\end{array}$ & 4.22 & 0.66 & Extremely Acceptable \\
\hline $\begin{array}{l}\text { 2. Affiliated to other organizations with } \\
\text { similar objectives }\end{array}$ & 4.24 & 0.65 & Extremely Acceptable \\
\hline $\begin{array}{l}\text { 3. Uses guided practice and monitoring } \\
\text { activities for trainees' development. }\end{array}$ & 4.24 & 0.66 & Extremely Acceptable \\
\hline $\begin{array}{l}\text { 4. Consists of different interactive } \\
\text { activities to enhance smocking skills } \\
\text { of the trainees }\end{array}$ & 4.2 & 0.65 & Extremely Acceptable \\
\hline $\begin{array}{l}\text { 5. Comprises deeper understanding of } \\
\text { the trainees on Smocked Throw } \\
\text { Pillow Production. }\end{array}$ & 4.24 & 0.66 & Extremely Acceptable \\
\hline Average Mean & 4.24 & 0.65 & Extremely Acceptable \\
\hline
\end{tabular}

of 4.26 and standard deviation of 0.64 with the verbal interpretation of Extremely Acceptable. Safety practices are consistently adhered with the mean of 4.2 and standard deviation of 0.65 with the verbal interpretation of Extremely Acceptable. Always displayed a positive attitude with the mean of 4.23 and standard deviation of 0.66 with the verbal interpretation of Extremely Acceptable. Community Improvement Plan as a Perception on Trainor's manners in handling Trainees on smocked throw pillows in terms of Personal Expertise average mean of 4.24 and standard deviation of 0.65 with the verbal interpretation Extremely Acceptable. 
EPRA International Journal of Multidisciplinary Research (IJMR) - Peer Reviewed Journal

Volume: 7 | Issue: 4 | April 2021|| Journal DOI: 10.36713/epra2013 || SJIF Impact Factor 2021: 8.047 || ISI Value: 1.188

$\begin{array}{cc}\text { Rating } & \text { Range } \\ 5 & 4.20-5.00 \\ 4 & 3.40-4.19 \\ 3 & 2.60-3.39 \\ 2 & 1.80-2.59 \\ 1 & 1.00-1.79\end{array}$

\author{
Description \\ Strongly Agree \\ Agree \\ Moderately Agree \\ Disagree \\ Strongly Disagree
}

Interpretation

Extremely Acceptable

Very Acceptable

Moderately Acceptable

Slightly Acceptable

Not Acceptable
The Mean Level of Community Improvement Plan as Work Determinants in Skills Training on Smocked Throw Pillow in terms of Coordination and Net Working. Active coordination with major stakeholders with the mean of 4.22 and standard deviation of 0.66 with the verbal interpretation of Extremely Acceptable. Affiliated to other organizations with similar objectives with the mean of 4.24 and standard deviation of 0.65 with the verbal interpretation of Extremely Acceptable. Uses guided practice and monitoring activities for trainees' development with the mean of 4.24 and standard deviation of 0.66 with the verbal interpretation of Extremely Acceptable. Consists of different interactive activities to enhance smocking skills of the trainees with the mean of 4.2 and standard deviation of 0.65 with the verbal interpretation of Extremely Acceptable. Consists of different interactive activities to enhance smocking skills of the trainees with the mean of 4.2 and standard deviation of 0.65 with the verbal interpretation of Extremely Acceptable. Comprises deeper understanding of the trainees on Smocked Throw Pillow Production. with the mean of 4.24 and standard deviation of 0.66 with the verbal interpretation of Extremely Acceptable.Community Improvement Plan as Work Determinants in Skills Training on Smocked Throw Pillow in terms of Coordination and Net Working with the average mean of 4.24 and standard deviation of 0.65 with the verbal interpretation of Extremely Acceptable.

Table 4. The Mean Level of Community Improvement Plan as Beneficiaries are participating in all stages of the production

\begin{tabular}{|c|c|c|c|c|}
\hline \multicolumn{2}{|c|}{$\begin{array}{l}\text { Beneficiaries are participating in all } \\
\text { stages of the production }\end{array}$} & MEAN & SD & INTERPRETATION \\
\hline \multicolumn{2}{|c|}{$\begin{array}{l}\text { 1. Enough time is spent with the community } \\
\text { to allow them to understand the programme. }\end{array}$} & 4.63 & 0.27 & Extremely Acceptable \\
\hline \multicolumn{2}{|c|}{$\begin{array}{l}\text { 2.Baseline information is obtained through } \\
\text { participatory techniques such as PRA }\end{array}$} & 4.19 & 0.76 & Very Acceptable \\
\hline \multicolumn{2}{|c|}{$\begin{array}{l}\text { 3.A community needs assessment is done } \\
\text { prior to planning. }\end{array}$} & 4.24 & 0.66 & Extremely Acceptable \\
\hline \multicolumn{2}{|c|}{$\begin{array}{l}\text { 4.Adopts and adapts new methods of } \\
\text { planning and implementation }\end{array}$} & 4.24 & 0.66 & Extremely Acceptable \\
\hline \multicolumn{2}{|c|}{$\begin{array}{l}\text { 5.Plans are in compliance with its existing } \\
\text { budget ,local agencies are involved in the } \\
\text { planning process. }\end{array}$} & 4.31 & 0.72 & Extremely Acceptable \\
\hline \multicolumn{2}{|c|}{ Average Mean } & 4.63 & 0.60 & Extremely Acceptable \\
\hline \multirow{2}{*}{$\begin{array}{l}\text { Rating } \\
5\end{array}$} & Range & Description & \multicolumn{2}{|c|}{ Interpretation } \\
\hline & $4.20-5.00$ & Strongly Agree & \multicolumn{2}{|c|}{ Extremely Acceptable } \\
\hline 4 & $3.40-4.19$ & Agree & \multicolumn{2}{|c|}{ Very Acceptable } \\
\hline 3 & $2.60-3.39$ & Moderately Agree & \multicolumn{2}{|c|}{ Moderately Acceptable } \\
\hline 2 & $1.80-2.59$ & Disagree & \multicolumn{2}{|c|}{ Slightly Acceptable } \\
\hline 1 & $1.00-1.79$ & Strongly Disagree & \multicolumn{2}{|c|}{ Not Acceptable } \\
\hline
\end{tabular}

The Mean Level of Community Improvement Plan as Beneficiaries are participating in all stages of the production. Enough time is spent with the community to allow them to understand the programme with the mean of 4.63 and standard deviation of 0.27 with the verbal interpretation of Extremely Acceptable. Baseline information is obtained through participatory techniques such as PRA with the mean of 4.19 and standard deviation of 0.76 with the verbal interpretation of Very Acceptable . A community needs assessment is done prior to planning with the mean of 4.24 and standard deviation of 0.66 with the verbal interpretation of Extremely Acceptable. Adopts and adapts new methods of planning and implementation with the mean of 4.24 and standard deviation of 0.72 with the verbal interpretation of Extremely Acceptable. Plans are in compliance with its existing budget, local agencies are involved in the planning process with the mean of 4.31 and standard deviation of 0.72 with the verbal interpretation of Extremely Acceptable. Community Improvement Plan as Beneficiaries are 
EPRA International Journal of Multidisciplinary Research (IJMR) - Peer Reviewed Journal Volume: 7 | Issue: 4 | April 2021|| Journal DOI: 10.36713/epra2013 || SJIF Impact Factor 2021: 8.047 || ISI Value: 1.188

participating in all stages of the production with the average mean of 4.63 and standard deviation of 0.60 with the verbal interpretation of Extremely Acceptable.

Table 5. The Mean Level of Community Improvement Plan as Local skill, knowledge and practices are mobilized in the production

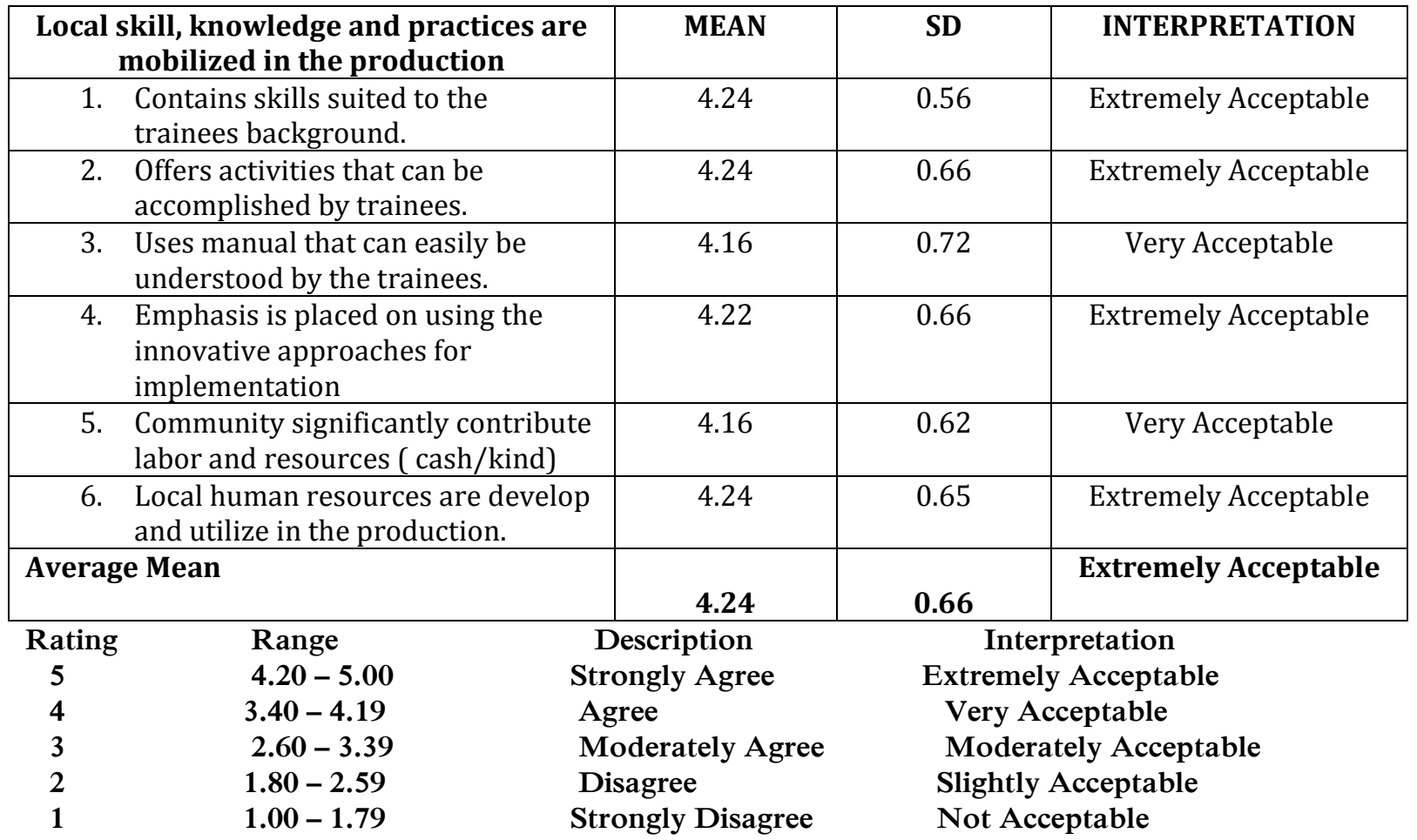

The Mean Level of Community Improvement Plan as Local skill, knowledge and practices are mobilized in the production. Contains skills suited to the trainees background. with the mean of 4.24 and standard deviation of 0.56 with the verbal interpretation of Extremely Acceptable. Offers activities that can be accomplished by trainees with the mean of 4.24 and standard deviation of 0.66 with the verbal interpretation of Extremely Acceptable. Uses manual that can easily be understood by the trainees with the mean of 4.16 and standard deviation of 0.72 with the verbal interpretation of Extremely Acceptable. Emphasis is placed on using the innovative approaches for implementation with the mean of 4.22 and standard deviation of 0.66 with the verbal interpretation of Extremely Acceptable. Community significantly contribute labor and resources ( cash/kind) with the mean of 4.16 and standard deviation of 0.62 with the verbal interpretation of Extremely Acceptable. Local human resources are develop and utilize in the production with the mean of 4.24 and standard deviation of 0.65 with the verbal interpretation of Extremely Acceptable. Community Improvement Plan as Local skill, knowledge and practices are mobilized in the production with the mean of 4.24 and standard deviation of 0.66 with the verbal interpretation of Extremely Acceptable.

Table 6. The Mean Level of Community Improvement Plan as Programs emphasize gender sensitivity

\begin{tabular}{|c|c|c|c|}
\hline Programs emphasize gender sensitivity & MEAN & SD & INTERPRETATION \\
\hline $\begin{array}{l}\text { 1. Women are actively involved in the } \\
\text { community need assessment }\end{array}$ & 4.25 & 0.65 & Extremely Acceptable \\
\hline $\begin{array}{llll}\text { 2. Pan activities addresses } & \text { to } \\
\text { women's needs }\end{array}$ & 4.3 & 0.72 & Extremely Acceptable \\
\hline $\begin{array}{l}\text { 3. Discuss gender sensitive issues to } \\
\text { community meetings }\end{array}$ & 4.2 & 0.61 & Extremely Acceptable \\
\hline $\begin{array}{l}\text { 4. At community level mix groups of } \\
\text { women and men are formed. As } \\
\text { well as women-only and men-only } \\
\text { groups. }\end{array}$ & 4.35 & 0.62 & Extremely Acceptable \\
\hline Average Mean & 4.4 & 0.68 & Extremely Acceptable \\
\hline
\end{tabular}




$\begin{array}{cc}\text { Rating } & \text { Range } \\ 5 & 4.20-5.00 \\ 4 & 3.40-4.19 \\ 3 & 2.60-3.39 \\ 2 & 1.80-2.59 \\ 1 & 1.00-1.79\end{array}$

The Mean Level of Community Improvement Plan as Programs emphasize gender sensitivity. Women are actively involved in the community need assessment with the mean of 4.25 and standard deviation of 0.66 with the verbal interpretation of Extremely Acceptable. Pan activities addresses to women's needs with the mean of 4.3 and standard deviation of 0.72 with the verbal interpretation of Extremely Acceptable. Discuss gender sensitive issues to community meetings with the mean of 4.2 and standard deviation of 0.61 with

\author{
Description \\ Strongly Agree \\ Agree \\ Moderately Agree \\ Disagree \\ Strongly Disagree
}

\author{
Interpretation \\ Extremely Acceptable \\ Very Acceptable \\ Moderately Acceptable \\ Slightly Acceptable \\ Not Acceptable
}

Table 7. The Mean Level of Community Improvement Plan as Systematic process of production

\begin{tabular}{|c|c|c|c|}
\hline Systematic process of production & MEAN & SD & INTERPRETATION \\
\hline $\begin{array}{l}\text { 1. Is versatile that can be used across } \\
\text { the curriculum }\end{array}$ & 4.3 & 0.66 & Extremely Acceptable \\
\hline $\begin{array}{l}\text { 2. Contains varied challenging tasks } \\
\text { that can be done by the trainees in } \\
\text { different aptitude level }\end{array}$ & 4.25 & 0.65 & Extremely Acceptable \\
\hline $\begin{array}{l}\text { 3. Can be easily managed by all } \\
\text { trainees. }\end{array}$ & 4.24 & 0.61 & Extremely Acceptable \\
\hline $\begin{array}{l}\text { 4. Provides activities which are } \\
\text { adopted to various learning style of } \\
\text { the trainees }\end{array}$ & 4.4 & 0.63 & Extremely Acceptable \\
\hline $\begin{array}{l}\text { 5. Designs are flexible in terms of } \\
\text { parts which can easily be added, } \\
\text { modified or omitted if necessary }\end{array}$ & 4.22 & 0.61 & Extremely Acceptable \\
\hline $\begin{array}{l}\text { 6. Information from monitoring is } \\
\text { used to improve production }\end{array}$ & 4.66 & 0.62 & Extremely Acceptable \\
\hline Average Mean & 4.25 & 0.66 & Extremely Acceptable \\
\hline Rating & \multirow{2}{*}{ Description } & \multicolumn{2}{|c|}{ Interpretation } \\
\hline $4.20-5.00$ & & \multicolumn{2}{|c|}{ Extremely Acceptable } \\
\hline $3.40-4.19$ & \multirow{2}{*}{$\begin{array}{l}\text { Agree } \\
\text { Moderately Agree }\end{array}$} & \multicolumn{2}{|c|}{ Very Acceptable } \\
\hline $2.60-3.39$ & & \multicolumn{2}{|c|}{ Moderately Acceptable } \\
\hline $1.80-2.59$ & $\begin{array}{l}\text { Moderately Agree } \\
\text { Disagree }\end{array}$ & \multicolumn{2}{|c|}{ Slightly Acceptable } \\
\hline $1.00-1.79$ & Strongly Disagree & \multicolumn{2}{|c|}{ Not Acceptable } \\
\hline
\end{tabular}

the verbal interpretation of Extremely Acceptable. At community level mix groups of women and men are formed. As well as women-only and men-only groups with the mean of 4.35 and standard deviation of 0.61 with the verbal interpretation of Extremely Acceptable. Community Improvement Plan as Programs emphasize gender sensitivity with the average mean of 4.4 and standard deviation of 0.68 with the verbal interpretation of Extremely Acceptable.
The Mean Level of Community Improvement Plan as Systematic process of production. Is versatile that can be used across the curriculum with the mean of 4.3 and standard deviation of 0.66 with the verbal interpretation of Extremely Acceptable. Contains varied challenging tasks that can be done by the trainees in different aptitude level with the mean of 4.25 and standard deviation of 0.65 with the verbal interpretation of Extremely Acceptable. Can be easily managed by all trainees with the mean of 4.24 and standard deviation of 0.66 with the verbal interpretation of Extremely
Acceptable. Provides activities which are adopted to various learning style of the trainees with the mean of 4.44 and standard deviation of 0.63 with the verbal interpretation of Extremely Acceptable. Designs are flexible in terms of parts which can easily be added, modified or omitted if necessary with the mean of 4.22 and standard deviation of 0.61 with the verbal interpretation of Extremely Acceptable. Information from monitoring is used to improve production with the mean of 4.66 and standard deviation of 0.62 with the verbal interpretation of Extremely Acceptable. Community Improvement Plan as Systematic process 
of production with the average mean of 4.25 and interpretation of Extremely Acceptable standard deviation of 0.65 with the verbal

Table 8. The Mean Level of Community Improvement Plan as Program Planning Implementation Monitoring and Assessment of Effectiveness

\begin{tabular}{|c|c|c|c|c|}
\hline \multicolumn{2}{|c|}{$\begin{array}{l}\text { Program Planning Implementation } \\
\text { Monitoring and Assessment of } \\
\text { Effectiveness }\end{array}$} & MEAN & SD & INTERPRETATION \\
\hline \multicolumn{2}{|c|}{$\begin{array}{l}\text { 1. Beneficiaries are participating in all } \\
\text { stages of the production. }\end{array}$} & 4.24 & 0.66 & Extremely Acceptable \\
\hline \multicolumn{2}{|c|}{$\begin{array}{l}\text { 2. Local skills, knowledge and } \\
\text { practices are mobilized in the } \\
\text { production of smocked throw } \\
\text { pillows }\end{array}$} & 4.24 & 0.66 & Extremely Acceptable \\
\hline \multicolumn{2}{|c|}{$\begin{array}{l}\text { 3. Program emphasizes gender } \\
\text { sensitivity. }\end{array}$} & 4.63 & 0.72 & Extremely Acceptable \\
\hline \multicolumn{2}{|c|}{$\begin{array}{l}\text { 4. Systematic process of } \\
\text { Implementation exists and skills } \\
\text { learned are incorporated in the } \\
\text { production of smocked throw } \\
\text { pillows. }\end{array}$} & 4.16 & 0.63 & Very Acceptable \\
\hline \multicolumn{2}{|c|}{$\begin{array}{l}\text { 5. Contains discussion that are } \\
\text { needed for better understanding of } \\
\text { the trainees on the effectiveness of } \\
\text { Smocked Throw Pillow Production } \\
\text { as work Determinant among the } \\
\text { Trainer }\end{array}$} & 4.63 & 0.65 & Extremely Acceptable \\
\hline \multicolumn{2}{|r|}{ Average Mean } & 4.25 & 0.66 & Extremely Acceptable \\
\hline Rating & Range & Description & \multicolumn{2}{|c|}{ Interpretation } \\
\hline 5 & $4.20-5.00$ & Strongly Agree & \multicolumn{2}{|c|}{ Extremely Acceptable } \\
\hline 4 & $3.40-4.19$ & Agree & \multicolumn{2}{|c|}{ Very Acceptable } \\
\hline 3 & $2.60-3.39$ & Moderately Agree & \multicolumn{2}{|c|}{ Moderately Acceptable } \\
\hline 2 & $1.80-2.59$ & Disagree & \multicolumn{2}{|c|}{ Slightly Acceptable } \\
\hline 1 & $1.00-1.79$ & Strongly Disagree & \multicolumn{2}{|c|}{ Not Acceptable } \\
\hline
\end{tabular}

The Mean Level of Community Improvement Plan as Program Planning Implementation Monitoring and Assessment of Effectiveness. Beneficiaries are participating in all stages of the production with the mean of 4.24 and standard deviation of 0.66 with the verbal interpretation of Extremely Acceptable. Local skills, knowledge and practices are mobilized in the production of smocked throw pillows with the mean of 4.24 and standard deviation of 0.66 with the verbal interpretation of Extremely Acceptable. Program emphasizes gender sensitivity with the mean of 4.63 and standard deviation of 0.72 with the verbal interpretation of Extremely Acceptable. Systematic process of Implementation exists and skills learned are incorporated in the production of smocked throw pillows with the mean of 4.16 and standard deviation of 0.63 with the verbal interpretation of Very Acceptable. Contains discussion that are needed for better understanding of the trainees on the effectiveness of Smocked Throw Pillow Production as work Determinant among the Trainer with the mean of 4.63 and standard deviation of 0.65 with the verbal interpretation of Extremely Acceptable. Community Improvement Plan as Program Planning Implementation Monitoring and Assessment of Effectiveness with the mean of 4.25 and standard deviation of 0.65 with the verbal interpretation of Extremely Acceptable. 
Table 9. The Mean Level of Community Improvement Plan as Organizational Structure and management

\begin{tabular}{|c|c|c|c|}
\hline $\begin{array}{c}\text { Organizational Structure and } \\
\text { management }\end{array}$ & MEAN & SD & INTERPRETATION \\
\hline $\begin{array}{l}\text { 1. Contains goals that are attainable } \\
\text { for the needs of the trainees on the } \\
\text { Smocked Throw Pillow Production. }\end{array}$ & 4.24 & 0.66 & Extremely Acceptable \\
\hline $\begin{array}{l}\text { 2. Provides goals that are easily } \\
\text { understood by the trainees }\end{array}$ & 4.16 & 0.65 & Very Acceptable \\
\hline $\begin{array}{l}\text { 3. Motivates the trainees to listen } \\
\text { attentively on clarity and consensus } \\
\text { exists on organization's vision and } \\
\text { goals, which are operationalized. }\end{array}$ & 4.17 & 0.66 & Very Acceptable \\
\hline $\begin{array}{l}\text { 4. } \begin{array}{l}\text { Decisions are made in } \\
\text { participatory way }\end{array}\end{array}$ & 4.24 & 0.65 & Extremely Acceptable \\
\hline 5. Delegation of authority occurs & 4.16 & 0.66 & Very Acceptable \\
\hline $\begin{array}{l}\text { 6. Personnel policies and procedures } \\
\text { exist, practiced and are gender } \\
\text { sensitive. }\end{array}$ & 4.24 & 0.65 & Extremely Acceptable \\
\hline $\begin{array}{l}\text { 7. Organization is operated under a } \\
\text { code of ethics }\end{array}$ & 4.24 & 0.28 & Extremely Acceptable \\
\hline $\begin{array}{llr}\text { 8. A program } & \begin{array}{r}\text { supportive } \\
\text { administration ( Procurement, }\end{array} \\
\text { Inventory and Admin.) exists. }\end{array}$ & 4.22 & 0.64 & Extremely Acceptable \\
\hline 9. $\begin{array}{l}\text { Communications are open and } \\
\text { spontaneous }\end{array}$ & 4.3 & 0.80 & Extremely Acceptable \\
\hline 10. Recording and filing system exists. & 4.24 & 0.79 & Extremely Acceptable \\
\hline Average Mean & 4.24 & 0.16 & Extremely Acceptable \\
\hline Rating & \multirow{2}{*}{ Ctugnolis } & \multicolumn{2}{|c|}{ Interpretation } \\
\hline $4.20-5.00$ & & \multicolumn{2}{|c|}{ Extremely Acceptable } \\
\hline $3.40-4.19$ & Agree & \multicolumn{2}{|c|}{ Very Acceptable } \\
\hline $2.60-3.39$ & Moderately Agree & \multicolumn{2}{|c|}{ Moderately Acceptable } \\
\hline $1.80-2.59$ & Disagree & \multicolumn{2}{|c|}{ Slightly Acceptable } \\
\hline $1.00-1.79$ & Strongly Disagree & \multicolumn{2}{|c|}{$\begin{array}{l}\text { Slightly Acceptable } \\
\text { Not Acceptable }\end{array}$} \\
\hline
\end{tabular}

The Mean Level of Community Improvement Plan as Organizational Structure and management. Contains goals that are attainable for the needs of the trainees on the Smocked Throw Pillow Production with the mean of 4.24 and standard deviation of 0.66 with the verbal interpretation of Extremely Acceptable. Provides goals that are easily understood by the trainees with the mean of 4.16 and standard deviation of 0.65 with the verbal interpretation of Very Acceptable. Motivates the trainees to listen attentively on clarity and consensus exists on organization's vision and goals, which are operationalized with the mean of 4.16 and standard deviation of 0.65 with the verbal interpretation of Very Acceptable. Decisions are made in a participatory way with the mean of 4.24 and standard deviation of 0.65 with the verbal interpretation of Extremely Acceptable. Personnel policies and procedures exist, practiced and are gender sensitive with the mean of 4.24 and standard deviation of 0.65 with the verbal interpretation of Extremely Acceptable. Organization is operated under a code of ethics with the mean of 4.24 and standard deviation of 0.28 with the verbal interpretation of Extremely Acceptable. A program supportive administration (Procurement, Inventory and Admin.) exists with the mean of 4.22 and standard deviation of 0.64 with the verbal interpretation of Extremely Acceptable. Communications are open and spontaneous with the mean of 4.3 and standard deviation of 0.80 with the verbal interpretation of Extremely Acceptable. Recording and filing system exists with the mean of 4.24 and standard deviation of 0.79 with the verbal interpretation of Extremely Acceptable. Community Improvement Plan as Organizational Structure and management exists with the average mean of 4.24 and standard deviation of 0.65 with the verbal interpretation of Extremely Acceptable. 
Table 10. The Mean Level of Community Improvement Plan as Programs emphasizes gender sensitivity.

\begin{tabular}{|c|c|c|c|c|}
\hline \multicolumn{2}{|c|}{ Programs emphasize gender sensitivity } & MEAN & SD & INTERPRETATION \\
\hline \multicolumn{2}{|c|}{$\begin{array}{l}\text { 1. Women are actively involved in the } \\
\text { community need assessment }\end{array}$} & 4.24 & 0.66 & Extremely Acceptable \\
\hline \multicolumn{2}{|c|}{$\begin{array}{l}\text { 2. Pan activities addresses to } \\
\text { women's needs }\end{array}$} & 4.16 & 0.66 & Very Acceptable \\
\hline \multicolumn{2}{|r|}{$\begin{array}{l}\text { 3. } \begin{array}{l}\text { Discuss gender sensitive issues to } \\
\text { community meetings }\end{array} \\
\end{array}$} & 4.24 & 0.76 & Extremely Acceptable \\
\hline \multicolumn{2}{|c|}{ Average Mean } & 4.24 & 0.65 & Extremely Acceptable \\
\hline \multicolumn{2}{|c|}{ Rating } & \multirow{2}{*}{$\begin{array}{c}\text { Description } \\
\text { Strongly Agree }\end{array}$} & \multicolumn{2}{|c|}{ Interpretation } \\
\hline 5 & $4.20-5.00$ & & \multicolumn{2}{|c|}{ Extremely Acceptable } \\
\hline 4 & $3.40-4.19$ & Agree & \multicolumn{2}{|c|}{ Very Acceptable } \\
\hline 3 & $2.60-3.39$ & Moderately Agree & \multicolumn{2}{|c|}{ Moderately Acceptable } \\
\hline 2 & $1.80-2.59$ & Disagree & \multicolumn{2}{|c|}{ Slightly Acceptable } \\
\hline 1 & $1.00-1.79$ & Strongly Disagree & \multicolumn{2}{|c|}{ Not Acceptable } \\
\hline
\end{tabular}

The Mean Level of Community Improvement Plan as Programs emphasize gender sensitivity. Women are actively involved in the community need assessment with the mean of 4.24 and standard deviation of 0.66 with the verbal interpretation of Extremely Acceptable. Pan activities addresses to women's needs with the mean of 4.16 and standard deviation of 0.66 with the verbal interpretation of Very Acceptable. Discuss gender sensitive issues to community meetings with the mean of 4.24 and standard deviation of 0.76 with the verbal interpretation of Extremely Acceptable. Community Improvement Plan as Programs emphasize gender sensitivity with the average mean of 4.24 and standard deviation of 0.65 with the verbal interpretation of Extremely Acceptable.

Table 11. There is significant difference between the Work determinant among the Trainer to Community Improvement Plan

\begin{tabular}{|l|c|c|c|}
\hline & Computed t-value & Critical t-value & Interpretation \\
$\begin{array}{l}\text { Workiner determinant among the } \\
\text { to } \\
\text { Community Improvement Plan }\end{array}$ & 3.274737505 & 1.684875122 & Significant \\
\hline
\end{tabular}

The study shows that there is significant difference between the Work determinant among the Trainer to Community Improvement Plan since the computed t-values is 3.27 and it is higher than critical $\mathrm{t}$-value of 1.68 regardless of it sign.

\section{CONCLUSION AND RECOMMENDATIONS}

Based on the findings of the study, the following conclusions were made.

Based on the findings of the study, the following conclusions were made. The respondents' Work Determinant among the Trainer in terms as a Trainee, Perception on trainors manner in handling trainees and Coordination and Networking were Extremely Acceptable. Community Improvement Plan in terms of Beneficiaries are participating in all stages of the production, Local skill, knowledge and practices are mobilized in the production, Programs emphasize gender sensitivity, Systematic process of production, Program planning Implementation monitoring and assessment of effectiveness, Organizational structure and management and
Program emphasize gender sensitivity were Extremely Acceptable. There significant effect between the work determinant among the trainer and community improvement plan.

\section{Recommendations}

Based on the conclusions drawn from the study, the following were recommended:

1. Recommend to produce more Smocked Throw Pillow

2. To instruct the community to make smoked throw pillow for their livelihood.

3. To show creative ways make Smoked Throw Pillow.

\section{REFERENCES}

1. Aguinis, Herman, and Kurt Kraiger. "Benefits of Training and Development for Individuals and Teams, Organizations, and Society." Annual Review of Psychology 60.1 (January 2009): 451474. DOI: 10.1146/annurev.psych.60.110707.163505

2. Arthur, Winfred A., Jr., Winston Bennett Jr., Pamela S. Edens, and Suzanne T. Bell. "Effectiveness of Training in Organizations: A 
Meta-analysis of Design and Evaluation Features." Journal of Applied Psychology 88.2 (April 2003): 234-245.DOI: 10.1037/00219010.88.2.234

3. Brown, Kenneth G., and Traci Sitzmann. "Training and Employee Development for Improved Performance." In APA Handbook of Industrial and Organizational Psychology. Vol. 2, Selecting and Developing Members for the Organization. Edited by Sheldon Zedeck, 469503. Washington, DC: American Psychological Association, 2011.

4. DOI: 10.1037/12170-000

5. Kraiger, Kurt. "Perspectives on Training and Development." In Handbook of Psychology. Vol. 12. Edited by Irving B. Weiner and Walter $C$. Borman, Daniel $R$. Ilgen, and Richard J. KIlimoski, 171-192. Hoboken, NJ: John Wiley, 2003

6. DOI: $10.1002 / 0471264385$

7. Noe, Raymond A., Alena D. M. Clarke, and Howard J. Klein. "Learning in the Twenty-firstcentury Workplace." Annual Review of Organizational Psychology and Organizational Behavior 1 (2014): 245-275.

8. DOI: 10.1146/annurev-orgpsych-031413-091321

9. https://en.wikipedia.org/wiki/Training and devel opment

10. Aguinis, Herman; Kraiger, Kurt (January 2009). "Benefits of Training and Development for Individuals and Teams, Organizations, and Society". Annual Review of Psychology. 60

11. (1): 451-474. doi:10.1146/annurev.psych.60.110707.163505. ISSN 0066-4308. PMID 18976113.

12. Bell, Bradford S.; Tannenbaum, Scott I.; Ford, J. Kevin; Noe, Raymond A.; Kraiger, Kurt (2017). "100 years of training and development research: What we know and where we should go". Journal of Applied Psychology. 102

13. (3): 305-323. doi:10.1037/apl0000142. hdl:1813/74878. ISSN 1939-1854. PMID 28125262. S2CID 26505012.

14. Campbell, J P (January 1971). "Personnel Training and Development". Annual Review of Psychology. 22 (1): 565-602. doi:10.1146/annurev.ps.22.020171.003025. ISSN 0066-4308.

15. Burke, Michael J.; Day, Russell R. (1986). "A cumulative study of the effectiveness of managerial training". Journal of Applied Psychology. 71 (2): 232-245. doi:10.1037/00219010.71.2.232. ISSN 0021-9010.

16. Birdi, Kamal; Allan, Catriona; Warr, Peter (1997). "Correlates and perceived outcomes of 4 types of employee development activity". Journal of Applied Psychology. 82 (6): 845-857. doi:10.1037/0021-9010.82.6.845. ISSN 00219010. PMID 9638086.

17. Marks, Michelle A.; Sabella, Mark J.; Burke, C. Shawn; Zaccaro, Stephen J. (2002). "The impact of cross-training on team effectiveness". Journal of Applied Psychology. 87 (1): 3-13. doi:10.1037/0021-9010.87.1.3. ISSN 0021-9010. PMID 11916213.
18. Rosemary Harrison (2005). Learning and Development. CIPD Publishing. p. 5. ISBN 9781843980506.

19. Patrick J. Montana \& Bruce H. Charnov (2000). "Training and Development". Management. Barron Educationally Series. p. 225. ISBN 9780764112768

20. Thomas N. Garavan; Pat Costine \& Noreen Heraty (1995). "Training and Development: Concepts, Attitudes, and Issues". Training and Development in Ireland. Cengage Learning EMEA. p. 1. ISBN 9781872853925.

21. Derek Torrington; Laura Hall \& Stephen Taylor (2004). Human Resource Management. Pearson Education. p. 363. ISBN 9780273687139.

22. Bell, Bradford S.; Kozlowski, Steve W. J. (2008). "Active learning: Effects of core training design elements on self-regulatory processes, learning, and adaptability". Journal of Applied Psychology. 93 (2): 296-316. doi:10.1037/00219010.93.2.296. hdl:1813/75102. ISSN 1939-1854. PMID 18361633

23. McDaniel, Mark A.; Schlager, Mark S. (June 1990). "Discovery Learning and Transfer of Problem-Solving Skills". Cognition and Instruction. $\quad 7 \quad$ (2): $129-159$. doi:10.1207/s1532690xci0702_3. ISSN 07370008 .

24. Keith, Nina; Frese, Michael (2005). "SelfRegulation in Error Management Training: Emotion Control and Metacognition as Mediators of Performance Effects". Journal of Applied Psychology. 90 (4): 677-691. doi:10.1037/0021-9010.90.4.677. ISSN 1939. 1854. PMID 16060786.

25. Wood, Robert; Kakebeeke, Bastiaan; Debowski, Shelda; Frese, Michael (April 2000). "The Impact of Enactive Exploration on Intrinsic Motivation, Strategy, and Performance in Electronic Search". Applied Psychology. 49 (2): 263-283. doi:10.1111/1464-0597.00014. ISSN 0269-994X.

26. Roberts, Karlene H. (July 1990). "Managing High Reliability Organizations". California Management Review. 32 (4): 101-113. doi:10.2307/41166631. ISSN 0008-1256. JSTOR 41166631. S2CID 154274951.

27. Peacock, Melanie; Steward, Eileen B.; Belcourt, Monica (2020). Understanding Human Resources Management. Alexis Hood. p. 185. ISBN 978-0-17-679806-2.

28. "The ADDIE Model for Instructional Design Explained". AIHR Digital. 2 November 2020. Retrieved 29 November 2020.

29. Peacock, Melanie; Steward, Eileen B.; Belcourt, Monica (2020). Understanding Human Resources Management. Alexis Hood. p. 189. ISBN 978-0-17-679806-2.

30. Peacock, Melanie; Steward, Eileen B.; Belcourt, Monica (2020). Understanding Human Resources Management. Alexis Hood. p. 190. ISBN 978-0-17-679806-2.

31. Peacock, Melanie; Steward, Eileen B.; Belcourt, Monica (2020). Understanding Human Resources Management. Alexis Hood. p. 191. ISBN 978-0-17-679806-2. 
32. Peacock, Melanie; Steward, Eileen B.; Belcourt, Monica (2020). Understanding Human Resources Management. Alexis Hood. p. 192. ISBN 978-0-17-679806-2.

33. "The Importance of Training Employees: 11 Benefits". Indeed Career Guide. Retrieved 29 November 2020.

34. Say, My. "Why Your Employee Training Is A Waste Of Time And Money -- And What To Do About It". Forbes. Retrieved 29 November 2020.

35. Aik, Chong Tek; Tway, Duane C. (March 2006). "Elements and principles of training as a performance improvement solution". Performance Improvement. 45 (3): 28-32. doi:10.1002/pfi.2006.4930450307. ISSN 10908811.

36. Stack, Laura ([@2013]). Managing employee performance : motivation, ability, and obstacles. [Highlands Ranch, CO]: Productivity Pro. ISBN 978-1-62723-025-4. OCLC 852507794. Check date values in: $\mid$ date $=($ help $)$

37. MacRae, Ian (Psychologist) (3 February 2017). Motivation and performance : a guide to motivating a diverse workforce. Furnham, Adrian. London. ISBN 978-0-7494-7814-8. OCLC 966315014.

38. Aguinis, Herman; Gottfredson, Ryan K.; Joo, Harry (1 March 2012). "Delivering effective performance feedback: The strengths-based approach". Business Horizons. 55 (2): 105-111. doi:10.1016/j.bushor.2011.10.004. ISSN 00076813.

39. Nelson, Bob. "A Dose of Positive Reinforcement Can Go a Long Way." T+D, vol. 67, no. 3, Mar. 2013, pp. 40-44. EBSCOhost, library.macewan.ca/full-record/bth/85852296.

40. Kozlowski, Steve W. J.; Bell, Bradford S. (15 April 2003), "Work Groups and Teams in Organizations", Handbook of Psychology, John Wiley \& Sons, Inc., doi:10.1002/0471264385.wei1214, hdl:1813/75229, ISBN 0471264385

41. Salas, Eduardo; Frush, Karen (24 August 2012). Improving patient safety through teamwork and team training. Salas, Eduardo, Frush, Karen. New York. ISBN 9780199875542. OCLC 811142213.

42. Rebecca, Page-Tickell (3 July 2014). Learning and development (1st ed.). London. ISBN 9780749469894. OCLC 883248797.

43. Brown, Judith (December 2002). "Training Needs Assessment: A Must for Developing an Effective Training Program". Public Personnel Management. $\quad 31 \quad$ (4): $\quad$ 569-578. doi:10.1177/009102600203100412. ISSN 00910260. S2CID 154852480.

44. Tannenbaum, S I; Yukl, G (January 1992). "Training and Development in Work Organizations". Annual Review of Psychology. 43 (1): 399-441. doi:10.1146/annurev.ps.43.020192.002151."131151.00 - Training and Development Specialists". www.onetonline.org. Retrieved 1 March 2019. 